\title{
TEORI EVOLUSIONISME (ANTROPOLOGI HUKUM)
}

$\begin{array}{ll}\text { Nama } & \text { : Larasati Permata Putri } \\ \text { Email } & : \text { Yayaspuput2105@gmail.com } \\ \text { Bp } & : 2010003600070 \\ \text { Perguruan Tinggi } & : \text { Universitas Eka Sakti } \\ & \text { Fakultas Hukum }\end{array}$

\section{A. PENDAHULUAN}

Evolusi sampai saat ini merupakan teori yang masih menjadi perdebatan diantara para ilmuan di seluruh dunia. Teori tersebut menyatakan terjadinya sebuah perubahan pada makhluk hidup atau spesies secara gradual (perlahanlahan). Perubahan yang dihasilkan membutuhkan waktu yang cukup lama dalam menghasilkan spesies atau makhluk hidup yang baru. Teori evolusi menjadi sebuah teori yang tenar ketika dipopulerkan oleh ilmuan Inggris Charles Darwin (1809-1882). Evolusi adalah konsep terpenting dalam biologi. Bahkan, seorang ahli genetika, Dodzhansky dalam Luthfi dan Khusnuryani (2005) mengatakan bahwa tidak ada yang masuk akal dalam biologi kecuali ditinjau dari sudut pandang evolusi. Teori evolusi menjelaskan mengapa jutaan spesies dapat eksis. Prinsip ini mempersatukan keseluruhan sejarah kehidupan. Secara ringkas evolusi menyatakan bahwa keanekaragaman bentuk kehidupan muncul sebagai hasil perubahan susunan genetikanya. Organisme-organisme modern merupakan keturunan dari bentuk-bentuk kehidupan sebelumnya yang mengalami modifikasi. Studi evolusi biologi memerlukan banyak pemahaman mengenai genetika, biokimi, embriologi, biogeografi, geologi, biologi, paleontologi, bioologi molekuler, dan lain sebagainya. Penolakan terhadap teori evolusi terkait dengan pernyataan Darwin bahwa spesies berkembang dari spesies yang sederhana ke makhluk hidup yang lebih kompleks. Darwin menyatakan bahwa mutasi adalah sumber keragaman yang selanjutnya melalui seleksi alam akan menyeleksi varian yang survive, selanjutnya evolusi terus berlangsung dan dapat menghasilkan spesies yang sangat berlainan dari spesies asalnya. Pernyataan evolusi Darwin ini mendapat tanggapan di kalangan ilmiah maupun masyarakat awam. Banyak tulisan ilmiah maupun pandangan tentang evolusi yang menyangkal peran mutasi bagi seleksi alam, mutasi dianggap tidak berperan karena mutasi bersifat acak, tidak terarah sehingga 12 menghasilkan mutan yang merugikan, kondisi gen di alam sebagian besar adalah homosigot, mutasi lebih banyak menyebabkan gen dominan menjadi resesif. Para kreasionis penentang evolusi memperselisihkan tingkat dukungan evolusi di kalangan ilmuwan. Discovery 
Institute telah mengumpulkan sekitar 600 ilmuwan sejak tahun 2001 untuk menandatangani petisi “A Scientific Dissent From Darwinism” (Ketidaksepakatan ilmiah dari Darwinisme) untuk menunjukkan bahwa terdapat sejumlah ilmuwan yang meragukan "evolusi Darwin". Pernyataan petisi ini tidak secara jelas menyatakan ketidakpercayaan pada evolusi, melainkan skeptisisme kemampuan "mutasi acak dan seleksi alam untuk bertanggung jawab terhadap kompleksitas kehidupan (Wikipedia, 2008). Berdasarkan hal ini tampak bahwa penolakan teori evolusi didasarkan peranan mutasi gen dan seleksi alam. Mengapa penganut kreasionisme menentang bahwa mutasi gen dan seleksi alam bukan merupakan faktor terjadinya proses evolusi? Alasan penolakan mereka berdasarkan alasan bahwa mutasi gen selalu merugikan, akan tetapi alasan ini tidak berdasarkan hasil empiris di tingkat penelitian molekuler. (Nusantari, 2013) Namun seiring dengan perjalanan waktu teori evolusi mengalami penyempurnaan atau modifikasi hingga sampai saat ini. Seperti halnya teori evolusi Darwin menjadi teori evolusi sintesis modern. Teori tersebut hingga sampai saat ini menjadi populer dikalangan masyarakat umum. Didalam gagasan teori evolusinya yang Darwin jelaskan dalam bukunya the Origin of Species terdapat dua pokok gagasan yang Darwin jelaskan dalam bukunya tersebut. Pertama adalah spesies-spesies yang ada sekarang ini merupakan keturunan dari spesies moyangnya.

\section{B. PEMBAHASAN}

Teori Evolusi Kebudayaan

Definisi Evolusi Kebudayaan

Evolusi kebudayaan bisa didefinisikan sebagai suatu perubahan atau perkembangan kebudayaan, seperti perubahan dari bentuk sederhana menjadi kompleks (Syaifudin, 2005 : 99 ). Perubahan itu biasanya bersifat lambat laun, paradigma yang berkaitan dengan konsep evolusi tersebut adalah evolusionalisme yang berarti cara pandang yang menekankan perubahan lambat laun menjadi lebih baik atau lebih maju dan dari sederhana ke kompleks.

Teori evolusi menggambarkan bahwa perubahan kebudayaan terjadi secara perlahan-lahan dan bertahap. Setiap masyarakat mengalami proses evolusi yang berbeda - beda. Oleh karena itu, masing - masing masyarakat menunjukkan kebudayaan yang berbeda - beda. Salah satu masyarakat dikenal telah maju, sedangkan masyarakat yang lain masih dianggap atau tergolong sebagai masyarakat yang belum maju.

\section{Teori Evolusi Kebudayaan Secara Universal}

Bahan etnografi dan etnografika yang tersebut dalam Bab I menimbulkan satu kesadaran diantara para cendekiawan dan para ahli filsafat di Eopa Barat mengenai besarnya keanekaragaman dari ciri - ciri ras, bahasa, dan kebudayaan umat manusia di dunia. Disamping itu kerangka cara berpikir evolusionisme universal tidak hanya diterapkan dalam ilmu biologi saja, tetapi juga telah menyebabkan timbulnya konsepsi tentang proses evolusi sosial secara universal. Konsep itu 
terutama dalam bagian kedua abad ke-19 sangat mempengaruhi cara berfikir para cendekiawan, para ahli hukum, para ahli sejarah kebudayaan, para ahli folklor, dan para ahli filsafat mngenai beberapa soal, misalnya soal asal - mula dan evolusi kelompok keluarga, asal - mula dan evolusi konsep hak milik, asal - mula dan evolusi negara, asal - mula dan evolusi religi dan sebagainya.

Menurut konsepsi tentang proses evolusi sosial universal, semua hal tersebut harus dipandang dalam rangka masyarakat manusia yang telah berkembang dengan lambat(berevolusi), dari tingkat - tingkat yang rendah dan sederhana, ke tingkat - tingkat yang makin lama makin tinggi dan kompleks. Proses evolusi seperti itu akan dialami oleh semua masyarakat manusia dimuka bumi, walaupun dengan kecepatan yang berbeda - beda. Itulah sebabnya pada masakini masih ada juga kelompok - kelompok manusia yang hidup dalam masyarakat yang bentuknya belum banyak berubah dari sejak zaman mahluk manusia baru timbul dimuka bumi, artinya mereka baru berada pada tingkat - tingkat permulaan dari proses evolusi sosial mereka.

\section{Konsep Evolusi Sosial Universal H.Spencer}

Ahli filsafat Inggeris H. Spencer ( 1820 - 1903 ) dianggap sebagai salah seorang pendekar ilmu antropologi, semua karya Spencer berdasarkan konsepsi bahwa seluruh alam itu baik yang berwujud nonorganis, organis, maupun superorganis,[1] berevolusi karena di dorong oleh kekuatan mutlak yang disebutnya evolusi universal ( Spencer 1876 : 1, 434 ). Spencer melihat perkembangan masyarakat dan kebudayaan dari tiap bangsa di dunia itu telah atau akan melalui tingkat - tingkat evolusi yang sama, namun ia tak mengabaikan fakta bahwa secara khusus tiap bagian masyarakat atau sub - sub kebudayaan bisa mengalami proses evolusi yang melalui tingkat yang berbeda - beda.

Suatu contoh misalnya teori Spencer mengenai asal mula religi. Pangkal pendirian mengenai hal itu adalah bahwa pada semua bangsa di dunia religi itu mulai karena manusia sadar dan takut akan maut, serupa dengan pendirian ahli sejarah kebudayaan E.B. Tylor.[2] Ia juga berpendirian bahwa bentuk religi yang tertua adalah penyembahan kepada roh - roh yang merupakan personifikasi dari jiwa orang - orang yang telah meninggal, teutama nenek moyangnya. Bentuk religi yang tertua ini pada semua bangsa di dunia akan berevolusi ke bentuk religi yang menurut Spencer merupakan tingkat evolusi yang lebih kompleks dan berdiferensiasi, yaitu penyembahan kepada dewa - dewa. Namun, walaupun religi dari semua bangsa di dunia pada garis besar evolusi universal akan berkembang dari tingkat penyembahan roh nenek moyang ke tingkat penyembahan dewa - dewa, secara khusus tiap bangsa dapat mengalami proses evolusi yang berbeda - beda.

Contoh lain mengenai anggapan Spencer tentang perbedaan antara proses evolusi universal yang seragam dan proses evolusi khusus yang berbeda - beda, tampak dalam teorinya tentang evolusi hukum dalam masyarakat. Dalam hubungan itu Spencer berpendirian bahwa hukum dalam masyarakat manusia pada mulanya adalah hukum keramat, karena merupakan aturan - aturan hidup dan bergaul, yang berasal dari para nenek moyang. Dengan demikian kekuatan dari hukum 
dalam masyarakat pada zaman permulaan itu terdiri dari kelompok - kelompok keluarga luas yang terdiri paling banyak 10 - 20 individu, berlandaskan pada ketakutan warga masyarakat akan kemarahan roh - roh nenek moyang apabila aturan - aturan tadi dilanggar.

Kalau masyarakat manusia menjadi lebih kompleks, maka hukum keramat yang bersifat statis tadi berkurang kekuatannya, karena tidak cocok lagi dengan keadaan, maka tumbuhlah hukum yang sekuler, yang mula - mula masih bedasarkan azas butuh - membutuhkan secara timbal balik antara warga masyarakat, makin diperlukan juga suatu kekuasaan otoriter untuk menjaga agar aturan - aturan sekuler itu ditaati warga masyarakat.

Pada tingkat evolusi sosial selanjutnya timbul masyarakat industri, dimana manusia lebih bersifat individualis dan dimana kekuasaan raja dan keyakinan terhadap raja keramat berkurang. Maka timbul lagi suatu sistem hukum yang baru, yang kembali berdasarkan azas saling butuh membutuhkan antara warga masyarakat secara timbal - balik, prosedur terjadinya undang undang adalah dengan perundingan antara wakil - wakil warga masyarakat dalam badan - badan legislatif.

\section{Teori Evolusi Keluarga J.J BACHOFEN}

Menurut Bachofen, diseluruh dunia keluarga manusia berkembang melalui empat tingkat evolusi.

a. Dalam zaman yang telah jauh lampau dalam masyarakat manusia ada keadaan Promiskuitas, dimana manusia hidup serupa sekawan binatang berkelompok, dan laki - laki serta wanita berhubungan dengan bebas dan melahirkan keturunannya tanpa ikatan. Kelompok keluarga inti sebagai inti masyarakat belum ada pada waktu itu. Keadaan ini dianggap merupakan tingkat pertama dalam proses perkembangan masyarakat manusia.

b. Lambat laun manusia sadar akan hubungan antara si ibu dengan anak - anaknya sebagai suatu kelompok inti dalam masyarakat, karena anak - anak hanya mengenal ibunya, tetapi tidak mengenal ayahnya. Dalam kelompok - kelompok keluarga inti serupa itu, ibulah yang menjadi kepala keluarga. Perkawinan antara ibu dan anak laki - laki dihindari, dengan demikian timbul adat exogami. Kelompok - kelompok keluarga ibu tadi itu menjadi luas karena garis keturunan untuk selanjutnya diperhitungkan melalui garis ibu, maka timbulah suatu keadaan masyarakat yang oleh oleh para sarjana waktu itu disebut matriarchate, ini adalah tingkat kedua dalam proses perkembangan masyarakat manusia.

c. Tingkat kemudian terjadi karena para pria tak puas dengan keadaan ini, lalu mengambil calon - calon isteri mereka dari kelompok - kelompok lain dan mebawa gadis - gadis itu ke kelompok mereka sendiri. Dengan demikian keturunan yang dilahirkan juga tetap tinggal dalam kelompok pria. Kejadian ini menyebabkan timbulnya secara lambat laun kelompok - kelompok keluarga dengan ayah sebagai kepala dan dengan meluasnya kelompok - kelompok serupa itu 
timbulah keadaan patriarchate. Ini adalah tingkat ketiga dalam proses perkembangan masyarakat manusia.

d. Tingkat terakhir terjadi waktu perkawinan diluar kelompok, yaitu exogami, berubah menjadi endogami karena berbagai sebab. Endogami atau perkawinan di dalam batas - batas kelompok menyebabkan bahwa anak - anak sekarang senantiasa berhubungan langsung dengan anggota keluarga ayah maupun ibu. Dengan demikian patriarchate lambat laun hilang, dan berubah menjadi suatu susunan kekerabatan yang oleh Bachofen disebut susunan parental.

\section{Teori Evolusi kebudayaan di Indonesia}

Teori evolsi kebudayaan, terutama teori evolusi keluarga dari J.J. Bachofen, juga diterapkan terhadap aneka - aneka warga kebudayaan Indonesia oleh ahli antropologi Belanda G.A. Wilken (1847-1891). Ia memulai kariernya pada tahun 1869 sebagai pegawai Pangreh Praja (Pamong Praja) Belanda di Buru (Maluku), Gorontalo dan Ratahan (Sulawesi Utara), Sipirok dan Mandailing (Sumatra Utara), Karangan-karangannya yang pertama sudah terbit sewaktu ia menjabat sebagai pegawai Pangreh Praja, yaitu mengenai sewa tanah dan mengenai adat pemberian nama di Minahasa (Wilken 1873; 1875), karangan etnografi singkat dari pulau Buru (1875-a), tetapi juga karangan - karangan teori tentang evolusi perkawinan dan berkeluarga berjudul over de primitieve Vormen van het Huwelijk en de oorsprong van her Gezin (18801881).[3] Dalam karangan yang terakhir ini ia menerangkan tingkat - tingkat evolusi Bachofen mengenai promiskuitas, mutriarkhat, patriarkhat, dan keluarga parental terurai di atas, dengan banyak bahan contoh yang diambilnya terutama dari Indonesia.[4]

Dengan demikian ia merumuskan teori - teori tentang sejumlah gejala kebudayaan dan kemasyarakatannya, misalnya tentang teknonimi ( Wilken 1875 ), tentang hakekat maskawin, yang menurut Wilken pada mulanya hanya merupakan alat untuk mengadakan perdamaian antara pengantin pria dan keluarga pengantin wanita setelah berlangsung kawin lari, suatu kejadian yang sering terdapat dalam masa peralihan antara tingkat matriarkhat ketingkat patriarkhat ( 1880:662,655-659,662-664) dan tentang sejumlah masalah serta gejala sosial dan kebudayaan lain.

\section{Teori Evolusi Kebudayaan L.H.Morgan}

Lewis H. Mogan (1818-1881) mula - mula adalah seorang ahli hukum yang lama tinggal di suku Indian Iroquois di daerarah Ulu Sungai St. Lawrence dan di sebelah selatan danau - danau besar Ontario dan Erie ( negara bagian New York ) sebagai pengacara bagi orang - orang Indian dalam soal - soal mengeni tanah. Dengan demikian ia mendapat pengetahuan tentang kebudayan orang - orang Indian. Karangan etnografinya yang pertama terbit dalam tuhun 1851, berjudul League of the Ho-de-no-Sau-nie or Iroquois. Karangan-karangan nya tentang orang Iroquois terutama 
terpusat kepada soal - soal susunan kemasyarakatan dan sistem kekerabatan, dalam hal ini Mogan telah memberikan sumbangan yang besar kepada ilmu antropologi pada umumnya.

Dalam memperhatikan sistem kekerabatan itu Morgan mendapatkan suatu cara untuk mengupas sistem kekerabatan dari semua suku bangsa di dunia yang jumlahnya beribu - ribu itu, yang masing - masing sangat berbeda bentuknya. Cara itu didasarkan pada gejala kesejajaran yang seringkali ada diantara sistem istilah kekerabatan ( system of kinship terminilogy ) dan kekerabatan (kiship system).

Menurut Morgan, masyarakat dari semua bangsa di dunia sudah atau masih akan menyelesaikan proses evolusi melalui delapan tingkat evolusi sebagai berikut :

a. Zaman Liar Tua,[5] yaitu zaman sejak adanya manusia sampai ia menemukan api, dalam zaman ini manusia hidup dari meramu, mencari akar - akar dan tumbuhan -tumbuhan liar.

b. Zaman Liar Madya, yaitu zaman sejak manusia menemukan api, sampai ia menemukan senjata busur - panah, dalam zaman ini manusia mulai merubah mata pencaharian hidupnya dari meramu menjadi pencari ikan disungai - sungai atau menjadi pemburu.

c. Zaman Liar Muda, yaitu zaman sejak manusia menemukan senjata busur - panah, sampai ia mendapatkan kepandaian membuat barang - barang tembikar, dalam zaman ini mata pencaharian hidupnya masih berburu.

d. Zaman Barbar Tua[6], yaitu zaman sejak manusia menemukan kepandaian membuat tembikar sampai ia mulai berternak atau bercocok tanan.

e. Zaman Barbar Madya, yaitu zaman sejak manusia berternak atau bercocok tanam sampai ia pandai membuat benda - benda dari logam.

f. Zaman Barbar Muda, yaitu zaman sejak menemukan kepandaian membuat benda-benda dari logam, sampai ia mengenal tulisan.

g. Zaman peradaban purba[7].

h. Zaman Peradaban Masakini.

Teori Morgan mengenai evolusi kebudayaan mendapat acaman yang sangat tajam dari para ahli Antropologi di Inggeris dan Amerika Serikat pada awal abd ke-20 ini, dan walaupun demikian Ia seorang warga Amerika yang mempunyai ilmu pengetahuan yang luas mengenai kehidupan masyarakat dan kebudayaan Indian penduduk pribumi Amerika, ia toh tidak dianggap sebagai pendekar ilmu Antropologi Amerika. Teori Morgan menjadi terkenal dikalangan cendikiawan komunis berkat F. Engels, yang sebagai pengarang yang bergaya lancar, telah befungsi membuat populer gagasan - gagasan Marx yang sering terlalu ilmiah sifatnya itu. 


\section{Teori Evolusi Religi E.B.Tylor}

Edward B. Tylor (1832-2927) adalah orang Inggeris yang mula - mula mendapatkan pendidikan dalam kesusateraan dan perdaban Yunani dan Rum Klasik dan baru kemudian tertarik dengan ilmu arkeologi. Sebagai orang yang dianggap memiliki kemahiran ilmu arkeologi, dalam tahun 1856 ia turut dengan suatu exspedisi Inggeris untuk menggali benda-benda arkeologi di mexiko. Dalam bukunya Primitive culture: Research into the Development of Mythology, Philosophy, Religion, Language, Art and Custom, asal mula religi adalah kesadaran manusia akan adanya jiwa. Kesadaran akan faham jiwa itu disebabkan karena dua hal, yaitu:

a. $\quad$ Perbedaan yang tampak pada manusia antara hal - hal yang hidup dan hal - hal yang mati. Satu organisma pada satu saat bergerak - gerak, artinya hidup, tetapi tak lama kemudian organisma itu juga tak bergerak lagi, artinya mati. Maka manusia mulai sadar akan adanya suatu kekuatan yang menyebabkan gerak itu, yaitu jiwa.

b. Peristiwa mimpi. Dalam mimpinya manusia melihat dirinya ditempat -tempat lain ( bukan ditempat dimana ia sedang tidur), maka manusia itu mulai membedakan antara tubuh jasmaninya yang ada ditempat tidur, dan suatu bagian lain dari dirinya yang pergi ketempat tempat lain. Bagian lain itulah yang disebut jiwa.

Sifat abstrak dari jiwa itu menimbulkan keyakinan pada manusia bahwa jiwa dapat hidup langsung, lepas dari tubuh jasmaninya. Pada waktu hidup, jiwa itu masih tersangkut kepada tubuh jasmani dan hanya dapat meninggalkan tubuh pada waktu manusia itu tidur atau pingsan. Karena pada saat serupa itu kekuatan hidup pergi melayang, maka tubuh berada dalam keadaan lemah.

Pada tingkat tertua dalam evolusi religinya, manusia percaya bahwa mahluk- mahluk halus itulah yang menempati alam sekeliling tempat tinggalnya. Mahluk - mahluk halus yang tinggal dekat tempat tinggal manusia itu, yang bertubuh halus sehingga tidak dapat tertangkap oleh panca indra manusia, mendapat tempat yang sangat penting dalam kehidupan manusia, sehingga menjadi obyek penghormatan dengan penyembahannya, yang disertai berbagai upacara berupa doa penyembahannya, yang disertai berbagai upacara doa, sajian, atau korban. Religi ini disebut animisme.

Tylor melanjutkan teorinya tentang asal mula religi dengan suatu uraian tentang evolusi religi, yang berdasarkan cara berpikir evolusionisme. Animisme pada dasarnya merupakan keyakinan kepada roh - roh yang mendiami alam semesta sekeliling tempat tinggal manusia, merupakan bentuk religi yang tertua. Pada tingkat kedua dalam evolusi religi, manusia yakin bahwa gerak alam yang hidup itu juga disebabkan adanya dibelakang peristiwa - peristiwa dan gejala alam itu. Sungai - sungai yang mengalir dan terjun kelaut, gunung - gunung yang meletus, gempa bumi, angin taufan, gerak matahari, tumbuhnya tumbuh - tumbuhan, disebabkan oleh mahluk halus yang menemepati alam. 
Jiwa alam itu kemudian dipersonifikasikan dan dianggap sebagai mahluk yang memiliki suatu kepribadian dengan kemauan dan pikiran, yang disebut dewa-dewa alam. Pada tingkat ketiga dalam evolusi religi, bersama dengan timbulnya susunan kenegaraaan dalam masyarakat manusia. Timbul pula keyakinan bahwa dewa - dewa alam itu juga hidup dalam suatu susunan kenegaraan, serupa dalam dunia makhluk manusia. Maka terdapat pula suatu susunan pangkat dewa - dewa, mulai dari raja sebagai dewa tertinggi, sampai dewa - dewa yang terendah pangkatnya. Susunan itu lambat laun menimbulkan kesadaran bahwa semua dewa itu pada hakekatnya hanya merupakan penjelmaan dari satu dewa saja, yaitu dewa yang tertinggi. Akibat dari keyakinan itu adalah berkembangnya keyakinan kepada satu tuhan dan timbulnya religi religi yang bersifat monotheisme sebagai tingkat yang terakhir dalam evolusi religi manusia.

Teori Evolusionisme Deterministik

Teori Evolusionisme Deterministik dapat dikatakan sebagai teori tertua di deretan teori antropologi. Teori ini dikembangkan oleh Lewis Henry Morgan dan Edward Burnet Tylor. Teori ini muncul dari anggapan adanya hukum universal yang mengendalikan perkembangan semua kebudayaan manusia. Berdasarkan teori ini setiap kebudayaan mengalami fase-fase atau evolusi. Lewis Henry Morgan (1818-1881) menggambarkan proses evolusi masyarakat dan kebudayaan dengan delapan tahap evolusi universal yang dituangkan dalam karyanya dengan judul Ancient Society. Delapan tingkat evolusi tersebut adalah zaman liar, zaman liar madya, zaman liar muda, zaman barbar tua, zaman barbar madya, zaman barbar muda, zaman peradaban purba dan zaman peradaban masa kini.

\section{PENUTUP}

Pada awal kajian manusia tentang kebudayaan, satu bentuk metoda berusaha untuk menggambarkan masyarakat dan kebudayaan ,primitife sebagai bahan acuan, maksudnya adalah untuk mendapatkan gambaran dan pengertian tentang tingkatan-tingkatan kuna dalam sejarah evolusi kebudayaan manusia dan dengan memberikan perbandingan masyarakat yang telah maju sebagai bentuk masyarakat dan kebudayaan yang tertinggi dari tingkat evolusi kebudayaan itu; Dengan menyusun suatu skema evolusi, digunakan konsep tentang survivals, yang dalam pengertian ini ialah unsur kebudayaan yang dilihat dari struktur dan sistemsistem nilai budaya yang ada pada satu waktu kurang fugnsional. Dengan adanya konsep survivals ini dapat dibuktikan, bahwa masyarakat itu telah berkembang ke tingkat yang lebih tinggi. Satu fenomena 
menarik dari konsep survivals pada saat ini adalah saling berdampingannya antara unsur kebudayaan tradisional dengan unsur kebudayaan modern; bila fenomena ini dihubungkan dengan persoalan tingkatan-tingkatan kebudayaan, tentu akan sulit ditentukan pada tingkat mana kebudayaan itu berada. Sejalan dengan perkembangan waktu, manusia mulai kritis=reaktif terhadap berbagai pandangan yang ada dan mencoba alternatif lain dalam pengkajian kebudayaannya, aliran evolusi klasik banyak mendapatkan kritik dan lambat laun mulai ditinggalkan. Walau demikian bukan berarti Evolusionisme Klasik ini sama sekali tidak berguna dalam pengkajian kebudayaan manusia, karena dalam beberapa hal ternyata ada juga manfaatnya, yaitu yang berkisaar pada : (1) Kajian itu berhasil membuat konsep tentang kebudayaan, sebagai konsep ilmiah yang tersusun secara sistematis. (2) Kajian itu telah menyadarkan kita kepada pengertian tentang aspek-aspek kebudayaan yang dapat diteliti secara teripisah-pisah. (3) Kajian itu telah mengajarkan prinsip-prinsip kontinuitas kebudayaan yang harus melandasi pendekatan yang realistis dalam menganalisa masalah perubahan masyarakat dan kebudayaan.

\section{DAFTAR PUSTAKA}

Gokma Toni Parlindungan S, Asas Nebis In Idem Dalam Putusan Hakim Dalam Perkara Poligami Di Pengadilan Negeri Pasaman Sebagai Ceriminan Ius Constitutum, Volume 2, Nomor 1, 2020.

Gokma Toni Parlindungan S, Pengisian Jabatan Perangkat Nagari Pemekaran Di Pasaman Barat Dalam Rangka Pelaksanaan Otonomi Daerah, Ensiklopedia Of Journal, Vol 1 No 2 Edisi 2 Januari 2019,

Harniwati, Peralihan Hak Ulayat Menurut Undang-Undang Nomor 18 Tahun 2004, Volume 1, Nomor 3, 2019.

Jasmir, Pengembalian Status Hukum Tanah Ulayat Atas Hak Guna Usaha, Soumatera Law Review, Volume 1, Nomor 1, 2018.

Jumrawarsi Jumrawarsi, Neviyarni Suhaili, Peran Seorang Guru Dalam Menciptakan Lingkungan Belajar Yang Kondusif, Ensikopedia Education Review, Vol 2, No 3 (2020): Volume 2 No.3 Desember 2020

Mia Siratni, Proses Perkawinan Menurut Hukum Adatdi Kepulauan Mentawai Di Sebelum Dan Sesudah Berlakunya Undang-Undang Nomor 1 Tahun 1974 Tentang Perkawinan, Ensiklopedia Of Journal, Vol 1 No 2 Edisi 2 Januari 2019, 
Remincel, Dimensi Hukum Pelanggaran Kecelakaan Lalu Dan Angkutan Jalan Lintas Di Indonesia, Ensiklopedia Social Review, Volume 1, Nomor 2, 2019.

R Amin, B Nurdin, Konflik Perwakafan Tanah Muhammadiyah di Nagari Singkarak Kabupaten Solok Indonesia 2015-2019, Soumatera Law Review, Volume 3, Nomor 1, 2020. 